\title{
布を創る 8
}

\section{絵師と型彫師と染師で創る現代きもの布地 \\ MARU. STUDIO 丸山正}

山㟝 昭 雄

型染小紋絵師，丸山正さんの今日の仕事の下敷きにな っているのは, 大阪芸大時代の油絵 (色と構図)，木を削 ったり磨き上げたオブジェとか粘土によるオブジェ(立体 溝成), アングラ演劇(パフォーマンス)である. 丸山さん は卒業後,グラフィックやイラストの世界にいて, NAAC 展で技術賞を受けた。

丸山正さんときものの世界との出会いは，丸山さんが 29才の時である。「絵を仕事にするのはやめよう.」と上 京「「ニートラルな状態」「生活のために㗢くなら，ネ クタイを付けた仕事をしよう」と吳服問屋に入り，販売 応援のため大型店の売場に立ったのがはじまりであった。 そしてここでは，アングラ演劇の下地が生きた。

丸山正さんの創る布は，きもの，帯，袋物や能楽に出 て来る翁(おきな)とか鵜匠の被るような帽子や，和様美 內小物類になる.

きものや帯の図案は，木の葉や布切れや伝統職人の使 ヴ道具などの形を絵柄にした「型」にし，色彩は黒を ベースに，藍・鼠・茶系を使う。花鳥風月に代表される 云統的なモチーフの柄行きではなく，華やかな小紋の色 放でもない丸山正の世界を創り出す.

最近は，樹の肌や編み立てた竹細工，時代物のワラ半 氏やアブラ紙の包装紙，それにダンボールなど，布以外 りモノから, 布地開発のソースを求めている.

また，以前から「きものに対してはシロウトでありた ?でも，布地に対しては自分の素材感を創りたい」と 思っていた，最近は，中国南部の穴明き布に出会ってか う，きものの布地に穴を明けたい衝動に駆られ，带も含 つて，穴明けの快感にはまっている。
丸山正さんの布地を㓣る作法は, 江戸時代の浮世絵師 の手法に似ている.

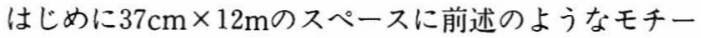
フの図案を型彫師が型にし，小紋染師が染め上げる.

場合によっては, 紬機織師に系の太さ, 夕テヨコの本 数および織り上げた風合いを，色と共に指示し，反物と してできて来た布地はさらに，部分的に別途に染上げた 柄布でパッチワーク仕上げしたり，小さな穴明け加工し たりして1反のきものの布地に完成させる。

帯地もきものと同じ作法で創り上げて行くが，色柄に ついては，ミスマッチの中に着る人の個性を生み出すも のではないかと考えている，つまり，同色や同柄でコン ビネーションを計るよりも，個性を活かしたミスマッチ のコーディネーションの方が，たのしさは倍増すると考 えているわけである。

現在の丸山正さんは，小千谷産地と組むことが多い。 はじめ，およそきもの地の既存の作法にはない,「きもの の図案というより，連続するオモシロイ形を表現」した 小紋柄のため,どこの紬織機師も染師も「これはきもの ではないからやりたくないと断られることも多かった。 色にしても基本の12色という伝統的な色見本帳にはない ものだからでもあった。

産地には, 何度か出会ううちに，きものの常識を破り ながらも，不思議な，それでいて新鮮な現代の和様美, 伝統にこだわらない自由な発想を受汁入れる職人グルー プができた。

丸山正さんは，自分のきものデザインの世界を「黒物 着(くろものき)」と名付けた。ことしで 8 年目を迎えた。

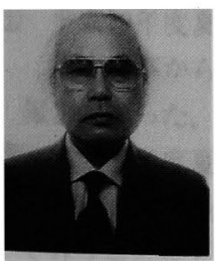

Textile Creation

著者紹介 AKIO YAMAZAKI

山㠃事務所代表

著者は,アパレル・きものを中心としたマーケティンクの研究を御専門とされ, 著書に「最新現代経営講座、 ーケティング」(総合法令，1996，共著)、「アパレル産業ハンドブック」(東洋経済新報社, 1996, 共著)他がある. 本稿では、「産業の空洞化」に抗して、日本のクリエーターたちの“布を創る”努力と業績を紹介していたたいた。 
「創る」という世界は, 前述の学生時代に色と構図と 立体構成を学んだことがべースとなっている。そして， 生まれて来た布地は, 歴史を遡って大層の昔, 平安の御 代の「媼(おうな)」や「翁(おきな)」の需囲気を醸(かも)

しているという事もある。

ふつうの布地を創る人の仕事は，アイテムの材料とし て提供したところで終わる。しかし，丸山正さんの場合 は，サブタイトルにあるように創るに留まらず，見せる ・売る世界まで含んでいる.

「きもの創り屋というのは, あくまでも“素材屋”で あるべきだ」と考えている背景は, 洋服の世界と違って, フォルムは完成された美であるから，素材で変化をもた せる必要があり，そこに自分のクリエーションの冥利(み ようり)があり, 存在感があると語る。

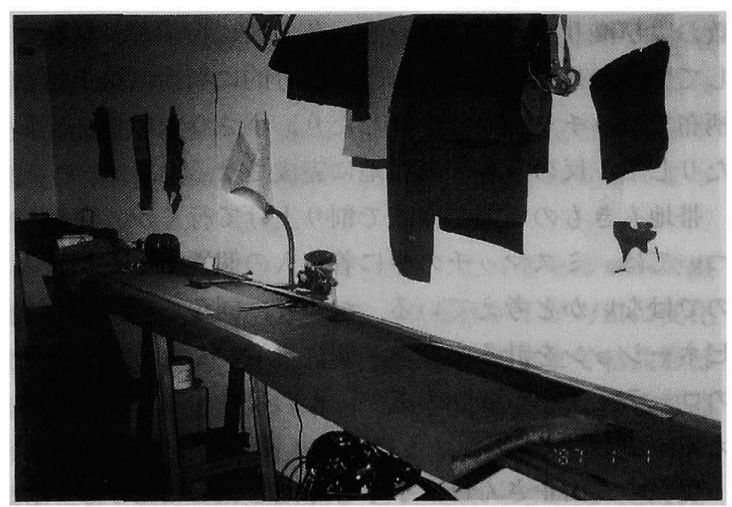

「布地に対しては，自分の素材感を㓣りたい」 という丸山正の仕事場

しかし，丸山正さんの場合はさらに「自分の布地を人 がまとうことによって，本人でも気づかなった新しい 世界を見つけ，そこに遊がことができる，そんな思いを 忠実に創っていることを，人に伝える場をつくり，直接 届けたい」と思っている。

つまり，展示のスペースも販売も丸山正さんのクリエ ーションの世界だと思っている.

案内状から始まって, 展示スペースの構成, 演出は, 学生時代のアングラ演劇が下敷きとなっている.

黒い $40 \mathrm{~cm} \times 20 \mathrm{~cm}$ 程の板の上に，たとえば，「波に月」 というテーマであれば，1反の布地は，さざ波に大波の ように流し置きにしたり，自然派を強調するように，40 $\mathrm{cm}$ 程の黄味色のワラをたばねなものも陳列小道具に使う。
最近は, 年に一度六本木で展示販売会を行う．その時 は, 高さ $50 \mathrm{~cm}$ 位にして畳一枚程の黑い板の上に, 1 点つ つ展示し，その会場の少し端に，前述の宗明け作業をす る板場をつくり, 豆電球をつけて仕事をする女性(黑物着 に羽織姿)を置いている.

もう一つの丸山正さんのクリエーションが「販売」の 作業である。

人の体に，1反の布を「巻き付ける」手法は，東京へ 出て来て呉服問屋にいた時, 派遣先で覚えたことである が、彼は,このパフォーマンスは, クリエーションのー 環と位置づける。

つまり，布地を着る人に「巻きつける」パフォーマン スは, 彼にすれば, 演劇的な要素をもったVP(ヴィシュ アルプレゼンテーション)であり,単なるモ/の移転では なく，人の変身願望とたのしみ願望を充足せしめる洒值 の共有であり，それは送り手にとっては，クリエイティ ブな活動だというわけである。

しかし,この場合, 自分をニュートラルな状態にして, 自分の恥部を捨てる精神にしておかないと成功しないと つけ加えた。

再度あげるが「布地を創る」という丸山正の世界の場 合は，創る・見せる・売るという行為を自分のインスピ レーションに基づいて，一貫させて表現させるところに ある。

1997年 1 月のテーマは,「タカガきもの——」であった 彼の母親が，何かの折にふっといったコトバであったか どんどん好きになっていくきもの創作活動に対する自分 へのなげかけのコトバでもあった、「……サレドももの となるかは，その後の仕事振りに表れていた。98年は4 月に「ごく・ふつうのきもの展」というテーマで発表す ることになっている.

紬という先染に後染をしたり，途中から切ってパッチ ワークにしたりして1反の布地にする型絵染手法は、こ れまでに出会ったことのない日本の様式美を䁔(かもし 出し，伝統の流れに，新しい水を汲むが如き新鲜な布地 創りとなっている.

88年に「きものデザイングランプリ」を受賞した

\section{MARU. STUDIO}

東京都麻布台 1 の 1 の 20 麻布台ユ二ハウス 109

電 話 : 03-3583-0814 